\title{
KAJIAN TERHADAP RENCANA PENGATURAN DISGORGEMENT DALAM PASAR MODAL INDONESIA*
}

\author{
*Raysa Mayasonda ${ }^{1}$, Lastuti Abubakar ${ }^{2}$, Ema Rahmawati $^{3}$ \\ Fakultas Hukum, Universitas Padjadjaran \\ Jalan Raya Bandung-Sumedang Km. 21 Jatinangor 45363 \\ *e-mail: raysamysnd@gmail.com ${ }^{1}$ \\ e-mail: 1.abubakar1962@gmail.com² \\ e-mail: ema.rahmawati@unpad.ac.id ${ }^{3}$
}

\begin{abstract}
Various kind of capital market violations show the characteristics of capital market violations that the loss is rarely realized by the investor. Currently, the regulation provides a way to resolve investor loss of capital market and the practice of resolving violations of the law in the capital market through the investor protection regulation is sometimes not satisfactory for the harmed investors. As a step to strengthen the law enforcement instruments, the Financial Services Authority (Otoritas Jasa Keuangan / OJK) issued a Draft Regulation (RPOJK) on OJK regarding Disgorgement and Disgorgement Fund to facilitate investor's legal protection against losses internally by itself. The purpose is to analyze the disgorgement mechanism regulation plan through the study of RPOJK so that it can be applied as a new settlement in the capital market and suitable with existing ways. The research method uses a normative juridical approach that is through the existing study of the rule of law that apply primary, secondary and tertiary legal materials, also from existing electronic literature. Based on the result of the study, it is concluded the plan of the disgorgement mechanism regulation as a form of refund through administrative mechanism is different from civil compensation and it can be applied as one of the investor's legal protections because the form of the order in disgorgement as a refund is considered effective, proportional and can be preventive.
\end{abstract}

Keywords: Disgorgement Arrangement Plan; The Protection of Investor; Investor Loss.

\section{Abstrak}

Berbagai pelanggaran pasar modal sangat memungkinkan menimbulkan kerugian investor namun jarang disadari. Regulasi perlindungan investor yang ada saat ini terkadang belum memuaskan bagi investor yang dirugikan. Sebagai langkah penguatan instrumen penegakan hukum, Otoritas Jasa Keuangan mengeluarkan RPOJK tentang Disgorgement dan Disgorgement Fund untuk memfasilitasi perlindungan hukum investor terhadap kerugian yang dialaminya. Tujuan penelitian ini untuk menganalisis rencana pengaturan mekanisme disgorgement melalui kajian terhadap RPOJK agar dapat diterapkan sebagai upaya penyelesaian baru dalam pasar modal dan berkesesuaian dengan upaya yang sudah ada. Metode penelitian menggunakan pendekatan yuridis normatif yaitu melalui penelaahan serta pengkajian kaidah-kaidah hukum yang berlaku melalui bahan hukum primer, sekunder, tersier, serta kepustakaan elektronik. Berdasarkan hasil kajian dapat dikemukakan rencana pengaturan mekanisme disgorgement oleh OJK sebagai bentuk pengembalian dana melalui upaya administrasi yang berbeda dengan mekanisme ganti rugi perdata dapat menjadi salah satu bentuk perlindungan hukum investor karena bentuk perintah dalam disgorgement sebagai pengembalian dana dinilai efektif, proporsional dan dapat bersifat preventif.

Kata kunci: Rencana Pengaturan Disgorgement; Perlindungan Investor; Kerugian Investor.

\footnotetext{
* Naskah diterima: 20 Juli 2020, direvisi: 18 September 2020, disetujui untuk terbit: 28 September 2020

Doi: $10.3376 /$ jch.v6i1.279
} 


\section{PENDAHULUAN}

Dalam mewujudkan kemakmuran rakyat maka perlu adanya pertumbuhan ekonomi dari berbagai sektor, salah satunya sektor pasar modal Indonesia. Pasar modal merupakan suatu sarana pembangunan perekonomian nasional dan kesejahteraan sosial (Saskia\&Rani, 2015). Diatur dalam Undang-Undang No. 8 Tahun 1995 tentang Pasar Modal yang hadir sebagai amanat dari Undang Undang Dasar 1945. Pasar modal sebagai tempat (dalam artian abstrak) bertemunya penawaran dan permintaan dana jangka menengah dan jangka panjang sehingga fungsinya adalah untuk mengalokasikan secara efisien arus dana dari unit ekonomi yang mempunyai surplus tabungan (saving surplus unit) kepada unit ekonomi yang mempunyai defisit tabungan (Adrian Sutedi, 2009).

Kegiatan ekonomi dipasar modal tidak akan bisa terhindar dari kemungkinan adanya pelanggaran peraturan perundang-undangan yang dilakukan di pasar modal itu sendiri. Dalam Undang-Undang Nomor 8 Tahun 1995 tentang Pasar Modal atau yang lebih dikenal dengan Undang-Undang Pasar Modal (UUPM) tercantum pelanggaran di pasar modal yang terbagi atas:
1. Pelanggaran administratif sebagaimana dimaksud di dalam Pasal 102 UUPM;

2. Pelanggaran pidana sebagaimana diatur di dalam Pasal 103 sampai dengan Pasal 110 UUPM; dan

3. Pelanggaran perdata sebagaimana dimaksud di dalam Pasal 111 UUPM.
Karena berkaitan dengan kegiatan perekonomian, maka pelanggaran hukum baik administrasi, perdata maupun pidana ini sangat berpeluang dan banyak menimbulkan kerugian finansial bagi para pihak di pasar modal terutama investor. Berdasarkan Peraturan Otoritas Jasa Keuangan Nomor 1/POJK.07/2014 tentang Lembaga Alternatif Penyelesaian Sengketa di Sektor Jasa Keuangan, terdapat beberapa pokok konsep dan struktur penyelesaian sengketa, yaitu Penyelesaian secara internal (internal dispute resolution) dimana pengaduan wajib diselesaikan terlebih dahulu oleh masing-masing lembaga jasa keuangan. Kemudian, penyelesaian secara eksternal (external dispute resolution) dalam hal tidak tercapai kesepakatan penyelesaian pengaduan dapat melakukan penyelesaian sengketa dengan cara: di luar pengadilan; atau melalui pengadilan (Ema\&Rai, 2016)

Terhadap kerugian investor yang timbul akibat adanya pelanggaran peraturan perundang-undangan di pasar modal sudah difasilitasi melalui hukum pasar modal Indonesia terkait upaya penyelesaian dengan menjamin penegakan prinsip keterbukaan informasi dan perlindungan investor, begitu pula pada kaidah internasional dalam Internasional Organization of Securities Commission (IOSCO) yang mengatur 3 prinsip utama dalam pasar modal yakni: 1. The Protection of Investors; 2. Ensuring that markets are fair, efficient and transparent; 3. The reduction of systemic risk (Objective and Principles of Securities Regulation IOSCO, 2017). 
Raysa Mayasonda, Lastuti Abubakar, Ema Rahmawati: Kajian Terhadap Rencana...

Wujud dari perlindungan hukum itu sendiri berupa legal structure dan legal substance dimana keduanya saling bersinergi dalam memberi kepastian dan perlindungan hokum (Haidar\&Fadilah, 2015)

Hukum pasar modal Indonesia pun mengenal upaya penyelesaian secara perdata didasarkan dalam UndangUndang Nomor 8 Tahun 1995 tentang Pasar Modal pasal 111 yang memberikan hak bagi pihak yang dirugikan pelanggaran undang undang pasar modal maupun peraturan pelaksanaannya untuk menuntut ganti rugi kepada pihak yang harus bertanggung jawab, yang pada prinsipnya dapat diselesaikan melalui pengadilan/litigasi. Namun selain penyelesaian melalui litigasi, sebagai bagian dari sektor jasa keuangan maka ketentuan yang berlaku dalam pasar modal juga dapat tunduk pada aturan yang lebih khusus melalui Peraturan Otoritas Jasa Keuangan Nomor 1/POJK.07/2014 tentang Lembaga Alternatif Penyelesaian Sengketa di Sektor Jasa Keuangan, yang mengarahkan agar setiap sengketa dalam sektor jasa keuangan di selesaikan melalui LAPS dalam setiap sektor, tentunya ketentuan ini berlaku juga dalam pasar modal dengan penyelesaian terhadap kerugian investor secara perdata diarahkan untuk dibawa dan diselesaikan dalam Badan Arbitrase Pasar Modal Indonesia (BAPMI) agar lebih cepat dan sederhana. Upaya perlindungan hukum investor terhadap kerugian akibat pelanggaran peraturan perundangundangan pasar modal juga diperkuat dengan adanya Peraturan Otoritas Jasa Keuangan Nomor 1/POJK.07/2013 Tentang Perlindungan Konsumen Jasa Keuangan, perlindungan konsumen tidak dapat dipisahkan dari kegiatan bisnis yang sehat (Evelyn, 2020). Sebagai bagian sektor jasa keuangan maka perlindungan konsumen yang dalam pasar modal menggunakan istilah investor bertujuan untuk meningkatkan kepercayaan investor dalam setiap aktivitas di pasar modal serta agar investor memiliki pemahaman atas hak dan kewajiban yang melekat pada dirinya sebagai subjek hukum pasar modal. Namun faktanya perlindungan yang diberi hukum pasar modal Indonesia belum sepenuhnya dapat menjamin keamanan investor dalam berinvestasi (Elvira dkk, 2020)

Pelanggaran di bidang pasar modal bersifat unik dilihat dari sisi pelanggarannya, pelakunya serta akibatnya (Jusuf Anwar, 2008). Hal ini yang menyebabkan pada kenyataan nya jarang bahkan sedikit kasus di pasar modal yang diselesaikan hingga ke pengadilan maupun melalui non litigasi sendiri, tentunya terjadi karena banyak faktor yang melatarbelakangi. Pada umumnya pelanggaran dipasar modal lebih banyak diselesaikan secara internal dengan menjatuhkan sanksi administratif maupun jika membahayakan sistem pasar modal baru dilanjutkan ke tahap penyidikan. Namun penegakan hukum terhadap kejahatan pasar modal belum dapat dilaksanakan sebagaimana mestinya (das sollen) (Iskandar\&Dadang, 2017). Begitu pula terhadap perlindungan hukum 
investor terhadap kerugian akibat pelanggaran peraturan perundangundangan di pasar modal sendiri pada saat ini terutama untuk pengembalian kerugian masih sangat jarang, investor masih belum banyak yang mengajukan tuntutan hak nya berupa ganti rugi baik ke pengadilan, maupun BAPMI dan lembaga lainnya sehingga dalam praktik sekarang ini aturan-aturan tentang perlindungan hukum investor terhadap kerugian yang sudah ada belum terlaksana secara efektif dan optimal bagi investor untuk mendapatkan kembali dananya melalui ganti rugi.

Berbagai aturan yang berlaku hingga saat ini sebagai bentuk kepastian hukum dalam upaya perlindungan hukum bagi investor terhadap kerugian yang dialaminya akibat dari adanya pelanggaran peraturan perundangundangan dalam pasar modal. Namun berbagai kerugian yang timbul akibat pelanggaran hukum pasar modal saat ini sangat jarang yang dapat terfasilitasi melalui aturan perlindungan investor yang ada secara perdata ini. Salah satu alasan terkuat belum efektifnya perlindungan hukum investor terhadap kerugian akibat pelanggaran hukum pasar modal karena mindset dari investor yang beranggapan bahwa setiap kerugian yang terjadi merupakan risiko serta konsekuensinya dalam berinvestasi yang tentunya mengakibatkan tidak adanya motivasi serta inisiatif dari investor untuk mengajukan ganti rugi serta meminta pertanggung jawaban kepada pelaku pelanggaran peraturan perundang- undangan di pasar modal, namun tidak jarang juga investor tidak sadar akan kerugian yang dialaminya karena karakteristik pelanggaran di pasar modal yang dilakukan secara rapih dan sempurna sehingga mengakibatkan investor tidak menyadari pelanggaran maupun kerugian yang ditimbulkan akibat pelanggaran tersebut.

Kemudian dari sisi investor juga terkesan malas untuk melakukan upaya perdata guna menuntut ganti rugi karena dalam pemikiran investor pengajuan ganti rugi yang ada saat sekarang membutuhkan prosedur yang masih belum sederhana dan belum efektif, serta mengingat ganti rugi dalam pasal 111 UUPM sama dengan perbuatan melawan hukum yang membutuhkan upaya pembuktian maka dirasa sulit untuk dilakukan oleh investor, sehingga memungkinkan investor untuk pasrah menerima kerugian dan menyerahkan penyelesaian pada otoritas pasar modal secara administrasi hingga dilanjutkan ke tahap pidana bila diperlukan. Hal ini lah yang menggambarkan kelemahan pengaturan perlindungan investor saat ini yang mengakibatkan jarangnya masuk tuntutan ganti rugi oleh investor ke pengadilan, maupun ke BAPMI sebagai penyelesaian yang disarankan dalam sengketa bisnis dan lembaga non litigasi lainnya.

Dalam era pengawasan dan pengaturan sektor jasa keuangan secara terintegrasi dibawah Otoritas Jasa Keuangan, maka sektor pasar modal merupakan salah satu sektor jasa 
keuangan yang tunduk pada pembinaan, pengawasan dan pengaturan oleh OJK (Ema\&Lastuti, 2019). Upaya perlindungan hukum investor terhadap kerugian terus dilaksanakan dengan dikeluarkannya rencana pengaturan melalui draft Rancangan Peraturan Otoritas Jasa Keuangan (RPOJK) tentang Disgorgement dan Disgorgement fund yang sudah rampung dan tinggal menunggu pengesahan agar menjadi suatu Peraturan Otoritas Jasa Keuangan (POJK) agar dapat berlaku sebagai upaya baru dalam penyelesaian terhadap kerugian yang dialami investor. Dalam bagian menimbangnya, menyatakan bahwa dalam rangka meningkatkan perlindungan kepada investor dan efektivitas penegakan hukum di bidang Pasar Modal, perlu adanya penguatan instrumen penegakan hukum yang dapat menciptakan efek jera bagi Pihak yang melakukan pelanggaran peraturan perundang-undangan di bidang Pasar Modal. Disgorgement sebagai suatu remedial action diharapkan dapat mencegah pihak yang melakukan pelanggaran menikmati keuntungan yang diperolehnya secara ilegal, mengkompensasi kerugian dari korban pelanggaran, mengandung unsur korektif, dan diharapkan dapat memberikan efek jera.

Terkait rencana OJK ini, perlu dilakukan kajian terhadap rencana pengaturan mekanisme disgorgement serta bagaimana nantinya pelaksanaan mekanisme ini diakomodasi dalam aturan. Dalam penelitian ini akan dilakukan kajian untuk melihat bagaimana rencana pengaturan mekanisme disgorgement dalam pasar modal agar dapat menjadi salah satu upaya perlindungan hukum investor yang efektif dan optimal dalam memberikan ganti rugi terhadap kerugian investor yang timbul akibat pelanggaran peraturan perundang-undangan di pasar modal Indonesia agar berkesesuaian dengan regulasi-regulasi perlindungan hukum investor yang sudah ada.

\section{METODE PENELITIAN}

Metode yang digunakan dalam penyusunan penelitian ini adalah metode penelitian Yuridis Normatif, Soerjono Soekanto mendefinisikan penelitian Yuridis Normatif sebagai suatu metode hukum yang dilakukan dengan meneliti bahan pustaka atau data sekunder sebagai bahan dasar untuk diteliti dengan cara mengadakan penelusuran terhadap peraturan-peraturan dan literatur-literatur yang berkaitan dengan permasalahan yang diteliti. Dengan spesifikasi Deskriptif Analitis yang menggambarkan, menelaah dan menganalisis secara sistematis tentang keadaan tertentu guna menggambarkan suatu keadaan dengan tepat. Bahan hukum yang digunakan:

a. Bahan Hukum Primer

Berupa Peraturan PerundangUndangan yaitu Undang Undang Dasar 1945, Undang-Undang No. 8 Tahun 1995 tentang Pasar Modal, Undang Undang No. 21 tahun 2011 tentang Otoritas Jasa Keuangan, Kitab Undang-Undang Hukum Perdata, Rancangan Peraturan Otoritas Jasa keuangan Tentang Disgorgement dan 
Disgorgement fund, serta peraturan perundang-undangan terkait lainnya.

b. Bahan Hukum Sekunder

Sebagai bahan yang memberi penjelasan erat hubungannya dengan bahan hukum primer seperti bukubuku ilmu hukum yang ditulis oleh para ahli, hasil penelitian dan hasil karya ilmiah baik yang diambil dari media cetak maupun media elektronik.

\section{HASIL DAN PEMBAHASAN}

\section{Disgorgement Sebagai Sarana Perlindungan Investor}

Rencana pengaturan mekanisme disgorgement ini terinisiasi dari The Securities and Exchange Commission (SEC) sebagai regulator untuk melakukan perlindungan investor di pasar modal Amerika Serikat yang telah lebih dahulu menerapkan dan mengenal ketentuan disgorgement. Dalam Black's Law Dictionary, Disgorgement as "the act of giving up something (such as profits illegally obtained) on demand or by legal compulsion". Pengenaan disgorgement menjadi wewenang komisi untuk memilih jalan melalui gugatan perdata pengadilan federal atau melalui hakim peradilan administratif SEC. Mekanisme disgorgement yang ada dalam SEC pun juga mengatur bahwa disgorgement bukan merupakan sebuah hukuman namun sebagai sarana untuk mencegah kekayaan yang tidak adil sehingga jumlah uang yang dikembalikan kepada pihak yang dirugikan juga riil sejumlah keuntungan yang diperoleh nya secara ilegal dan tidak boleh dilebihkan jumlahnya.
Berkaitan dengan disgorgement, terdapat ketentuan fair fund yang dikenal pada tahun 2002, fair fund bagi investor diberlakukan sebagai tempat/wadah keuntungan investor yang telah kehilangan uang karena aktivitas ilegal dari individu atau perusahaan yang melanggar aturan sekuritas. Fair fund dikenal saat pemberlakuan SarbanesOxley Act yang memperluas kekuatan SEC untuk mengkompensasi investor yang ditipu, pada bagian 308(a) dari ketentutannya, mengotorisasi SEC untuk menambahkan denda sipil yang dibayarkan dalam tindakan penegakan hukum melalui disgorgement fund yang disebut dengan istilah Fair fund, dan mendistribusikannya kepada para korban pelanggaran sekuritas, kekuasaan ini menjadi unik diantara lembaga-lembaga federal (Urska, 2015)

Dikarenakan pengaturan perlindungan investor saat ini masih memiliki kelemahan terhadap kerugian investor dalam memberikan ganti rugi menjadikan disgorgement sebagai langkah baru yang akan diterapkan oleh OJK. Kajian terhadap rencana pengaturan mekanisme disgorgement pada pasar modal Indonesia dilakukan berdasarkan pada ketentuan yang ada dalam rencana pengaturan terkait Disgorgement dan Disgorgement Fund. OJK menggunakan istilah disgorgement sebagai bentuk pengembalian dana yang diperintahkan kepada pelaku pelanggaran peraturan perundang-undangan di pasar modal melalui suatu perintah tertulis. Sebagai bentuk pengembalian dana, maka jumlah 
dana yang dikembalikan sejumlah keuntungan yang diperoleh/kerugian yang dihindari secara tidak sah/melawan hukum, sehingga pengembalian dilakukan dengan jumlah yang riil serta tidak bisa dikurangi maupun dilebihkan.

Secara hukum, istilah disgorgement yang digunakan OJK merupakan dua hal yang berbeda dengan istilah ganti rugi. Mekanisme ganti rugi merupakan upaya hukum yang berdiri sendiri dan termasuk dalam upaya penyelesaian secara perdata di pasar modal yang dilakukan dengan mengajukan gugatan ganti rugi baik melalui pengadilan maupun lembaga penyelesaian sengketa di luar pengadilan. Hukum acara perdata mengatur tentang bagaimana cara mengajukan tuntutan hak, memeriksa serta memutusnya, dan pelaksanaan dari putusannya (Sudikno Mertokusumo, 2013). Dalam hal ganti kerugian, sebagai tuntutan hak untuk mendapatkan perlindungan hukum dapat mengajukan gugatan atas perbuatan melawan hukum maupun wanprestasi yang petitum nya meminta ganti rugi, sehingga dibutuhkan proses pembuktian sebagai proses penting untuk menentukan seseorang bersalah, melanggar hukum atau tidak serta berakibat dijatuhkan sanksi atau tidak. Pada saat itu hakim dibutuhkan untuk menyelidiki, mempertimbangkan atau memberi alasanalasan atas kebenaran hubungan hukum sehingga dapat menjatuhkan putusan yang mengabulkan ganti rugi terhadap pihak yang dirugikan.

Dalam mekanisme ganti rugi juga mengenal ganti rugi materil, hitungan kerugian sejumlah uang yang dirugikan dan dimungkinkan pula kesempatan bagi pihak yang dirugikan untuk mengajukan tuntutan ganti rugi secara immateril yang melebihkan jumlah hitungan kerugian yang diperkirakan oleh korban. Di lain sisi, mekanisme disgorgement sebagai bentuk pengembalian dana merupakan sebuah bentuk upaya penyelesaian baru yang difasilitasi oleh OJK secara internal yang dilakukan dalam penyelesaian secara administrasi, yang mengakibatkan pengenaan disgorgement ini tidak dapat berdiri sendiri melainkan melekat pada saat OJK menjatuhkan sanksi administrasi kepada pelaku pelanggaran peraturan perundang-undangan pasar modal.

Rencana pengaturan disgorgement dipertimbangkan oleh OJK sebagai bentuk penegakan hukum yang efektif, proporsional, dan yang paling penting sebagai tindakan preventif, dimana setiap OJK melakukan penyelesaian terhadap pelanggaran pasar modal secara internal/administrasi dengan mengeluarkan sanksi administrasi, OJK juga dapat memberikan perintah kepada pelaku pelanggaran untuk melakukan pengembalian dana yang diperoleh atau dihindarinya secara melawan hukum tersebut, karena biasanya pada sanksi administrasi yang dijatuhkan oleh OJK lebih banyak menjatuhkan denda sebagai bentuk pembayaran sejumlah uang ke kas negara namun biasanya jumlahnya juga tidak terlalu besar sehingga dengan adanya pengembalian dana secara riil yang sesuai dengan jumlah keuntungan yang diperoleh atau kerugian yang 
dihindari oleh pelaku pelanggaran hukum pasar modal maka tujuan OJK dalam rencana pengaturan mekanisme disgorgement untuk menciptakan serta memberikan efek jera kepada pelaku pelanggaran diharapkan dapat tercapai dan terlaksana.

Apabila dilihat dari segi mekanismenya, disgorgement dikenakan pada saat OJK menjatuhkan sanksi administrasi namun belum langsung diberikan kepada investor maupun pihak yang dirugikan. Disgorgement sebagai bentuk pengembalian dana yang kemudian bila dana yang terkumpul sudah memadai barulah dibentuk disgorgement fund sebagai wadah yang akan menerima klaim dari pihak-pihak yang dirugikan lalu mendistribusikannya kepada pihak tersebut. Sehingga pada prinsipnya pengaturan mekanisme disgorgement merupakan upaya yang juga dimaksudkan untuk penegakan hukum yang disiplin bagi pelaku pelanggaran hukum pasar modal yang pada akhirnya dapat memberikan efek jera, sangat memungkinkan tidak ada pihak yang merasa dirugikan karena akibat dari pelanggaran dipasar modal yang terkadang tidak bisa dirasakan secara langsung. Hal ini menujukkan bahwa rencana pengaturan mekanisme disgorgement tidak hanya sebatas untuk perlindungan hukum investor terhadap kerugian yang dialaminya akibat pelanggaran peraturan perundangundangan di pasar modal namun lebih jauh lagi memiliki tujuan untuk keseimbangan dan menciptakan pasar yang sehat agar dapat memberikan perlindungan hukum, kepastian hukum serta meningkatkan kepercayaan investor dalam pasar modal Indonesia.

Praktik penyelesaian pelanggaran peraturan perundang-undangan di pasar modal salah satunya dapat dilihat dari praktik insider trading yang marak terjadi dan sangat memungkinkan menimbulkan kerugian investor, seperti dalam dugaan praktik insider trading dalam kasus PT. Gas Negara Tbk. dimana otoritas pasar modal pada saat itu menyelesaikan secara administrasi dengan memberikan sanksi administratif berupa denda terhadap PT. Gas Negara Tbk (PGAS) berdasar pelanggaran keterbukaan informasi dalam UUPM dan tidak terbukti sebagai suatu pelanggaran pidana yang mengakibatkan investor sebagai pihak yang memungkinkan dirugikan tidak menyadari kerugian yang ditimbulkan dari pelanggaran tersebut, sehingga penyelesaian perdata pun jarang terlaksana. Hal ini sebagai salah satu yang menggambarkan pelaksanaan penyelesaian pelanggaran peraturan perundang-undangan di pasar modal lebih banyak diselesaikan secara internal otoritas dan diberikan sanksi administrasi namun jarang menyangkut ranah perdata untuk melindungi investor dari kerugian yang dapat dialaminya.

Berdasarkan pertimbangan OJK dalam rencana pengaturan mekanisme disgorgement ini, tentunya sangat relevan dengan kondisi yang menggambarkan kelemahan terhadap penyelesaian kerugian akibat pelanggaran peraturan 
perundang-undangan di pasar modal, dimana OJK sebagai Otoritas di pasar modal lebih paham dan lebih dulu mengetahui ada tidaknya dugaan pelanggaran, pengenaan disgorgement tentunya lebih efektif daripada hanya sebatas denda administratif untuk memberikan efek jera kepada pelaku pelanggaran peraturan perundangundangan pasar modal serta lebih efektif dari pada mengajukan gugatan ganti rugi perdata ke pengadilan maupun luar pengadilan yang lebih sulit dalam pembuktiannya. Begitupun dari sisi investor yang dirugikan, jangankan untuk mengajukan ganti rugi secara perdata, terhadap kerugian yang dialami akibat pelanggaran saja sulit untuk disadari oleh investor, dengan adanya pengenaan disgorgement diharapkan dapat meningkatkan kesadaran investor akan kerugian sebagai akibat dari adanya pelanggaran terhadap peraturan perundang-undangan di pasar modal dan investor memiliki kesempatan untuk menerima pengembalian dana yang mereka miliki melalui mekanisme Disgorgement dan Disgorgement fund nantinya.

\section{Kewenangan OJK Dalam Rencana Pengaturan Mekanisme Disgorgement}

Dalam rencana pengaturannya, OJK berwenang mengenakan disgorgement terhadap Pihak yang melakukan pelanggaran peraturan perundangundangan di bidang Pasar Modal, didasarkan pada keputusan administratif yang ditetapkan oleh OJK dalam bentuk
Perintah Tertulis. Penetapan Perintah Tertulis sehubungan dengan disgorgement ini dilakukan bersamaan dengan ditetapkannya sanksi administratif kepada Pihak yang melakukan pelanggaran peraturan perundang-undangan di bidang Pasar Modal. Pengeluaran rencana pengaturan terkait Disgorgement dan Disgorgement fund ini tentunya berangkat dari kewenangan yang dimiliki OJK dalam Undang-Undang Nomor 21 Tahun 2011 Tentang Otoritas Jasa Keuangan pasal 8 untuk melaksanakan tugas pengaturan serta pasal 9 untuk melaksanakan tugas pengawasan, yang lebih spesifiknya dalam pasal 8 huruf i, OJK berwenang "menetapkan peraturan mengenai tata cara pengenaan sanksi sesuai dengan ketentuan peraturan perundang undangan di sektor jasa keuangan."

Namun pengenaan sanksi yang dilakukan oleh OJK terbatas dalam upaya administrasi sebagaimana diatur dalam pasal 9 huruf g, yakni "menetapkan sanksi administratif terhadap pihak yang melakukan pelanggaran terhadap peraturan perundang-undangan di sektor jasa keuangan" Bentuk sanksi ini pun limitatif, yakni hanya dapat berupa:

a. Peringatan tertulis

b. Denda

c. Pembatasan kegiatan usaha

d. Pembekuan kegiatan usaha

e. Pencabutan izin usaha

f. Pembatalan persetujuan

g. Pembatalan pendaftaran

Apabila diartikan secara kalimat, perintah tertulis pengenaan disgorgement 
belum dapat digolongkan ke dalam salah satu bentuk sanksi administrasi. Akan tetapi memungkinkan untuk diartikan bahwa dalam melakukan upaya penyelesaian secara administrasi (internal) terhadap pelanggaran peraturan perundang-undangan di pasar modal yang mengakibatkan adanya kerugian secara materil bagi investor, dalam mengeluarkan keputusan administratifnya OJK dapat menjatuhkan sanksi administratif dan sekaligus mengeluarkan perintah tertulis pengenaan disgorgement agar pelaku pelanggaran dapat melakukan pengembalian keuntungan yang diperoleh atau kerugian yang dihindari secara tidak sah/melawan hukum yang dilakukannya kepada para investor.

Berkaitan dengan perintah tertulis ini lah mengarah pada kewenangan dalam pasal 9 huruf d, "memberikan perintah tertulis kepada Lembaga Jasa Keuangan dan/atau pihak tertentu;" namun dari beberapa kewenangan yang telah disebutkan diatas tidak dicantumkan batasan kewenangan dalam penjelasan pasalnya. Adapun karena kewenangan yang dimiliki OJK dalam pasal 8 saling berkaitan dengan pasal 9, maka dalam penjelasan pasal 8 huruf $\mathrm{f}$ dapat dilihat bahwa yang dimaksud dengan "perintah tertulis" adalah perintah secara tertulis untuk melaksanakan atau tidak melaksanakan kegiatan tertentu guna memenuhi ketentuan peraturan perundang-undangan di sektor jasa keuangan dan/atau mencegah dan mengurangi kerugian Konsumen, masyarakat, dan sektor jasa keuangan.
Perintah tertulis diberikan antara lain untuk mengganti pengurus atau pihak tertentu di Lembaga Jasa Keuangan, menghentikan, membatasi, atau memperbaiki kegiatan usaha atau transaksi, menghentikan atau mengubah perjanjian antara Lembaga Jasa Keuangan dengan pihak lain yang diduga merugikan Konsumen, masyarakat, dan sektor jasa keuangan, serta menyampaikan informasi, dokumen, dan/atau laporan tertentu kepada OJK.

Berdasarkan penjelasan pasal mengenai perintah tertulis, secara tersurat sudah dibatasi dan diberikan bentuk bentuk tindakan yang dapat dilakukan dalam pemberian perintah tertulis, namun dapat diperluas karena perintah tertulis diberikan untuk melaksanakan atau tidak melaksanakan kegiatan tertentu guna memenuhi ketentuan peraturan perundang-undangan di sektor jasa keuangan dan/atau mencegah dan mengurangi kerugian Konsumen, masyarakat, dan sektor jasa keuangan, sehingga bagi OJK dimungkinkan untuk diperluas dengan melakukan perintah melaksanakan kegiatan tertentu dalam hal ini mengembalikan sejumlah uang (Disgorgement) guna mencegah/ mengurangi kerugian konsumen yang dalam pasar modal biasanya pihak yang rawan untuk dirugikan adalah investor.

Melihat berbagai pasal yang telah dijabarkan dan saling memiliki keterkaitan satu sama lainnya, maka yang dilakukan OJK merupakan bentuk perluasan kewenangan terhadap UndangUndang OJK dalam rencana pengaturan 
Raysa Mayasonda, Lastuti Abubakar, Ema Rahmawati: Kajian Terhadap Rencana...

mekanisme Disgorgement dan Disgorgement fund ini.

\section{SIMPULAN}

Berdasarkan pembahasan yang penulis kemukakan, mengingat pentingnya sektor pasar modal dalam perekenomian suatu negara, dibutuhkan pasar yang sehat dan dapat menjamin perlindungan investor. Maka penulis menyimpulkan:

1. Perlindungan hukum terhadap investor atas kerugian akibat pelanggaran peraturan perundangundangan di pasar modal pada saat ini belum efektif dan optimal karena belum terdapatnya mekanisme yang sederhana untuk dapat menuntut ganti kerugian dalam rangka perlindungan investor pasar modal, selain itu sebagian besar investor menganggap kerugian merupakan bagian dari risiko investasi.

2. Mekanisme disgorgement sebagai rencana yang masih berbentuk Rancangan Peraturan Otoritas Jasa Keuangan dapat menjadi salah satu bentuk perlindungan hukum terhadap investor atas kerugian yang timbul akibat pelanggaran peraturan perundang-undangan di pasar modal, karena bentuk perintah dalam disgorgement dinilai efektif, proporsional, dan dapat bersifat preventif.

\section{UCAPAN TERIMAKASIH}

Penulis mengucapkan terimakasih kepada :
1. Bapak Dr. Eviandi Ibrahim S.H., M.Hum selaku Ketua Sekolah Tinggi Ilmu Hukum (STIH) Putri Maharaja Payakumbuh

\section{DAFTAR PUSTAKA}

Adrian Sutedi. (2009). Segi-Segi Hukum Pasar Modal, Jakarta: Ghalia Indonesia.

Elvira Fitriyani Pakpahan, Vivi Prisilla, Dicky, Yuni Adriana, dan Malau. (2020). Peran dan Kewenangan Profesi Penunjang Pasar Modal (Notaris) dalam Menghadapi Era Globalisasi. Jurnal Cendekia Hukum, Vol 5 No. 2.

Ema Rahmawati dan Lastuti Abubakar, (2019). Peranan Penyelesaian Sengketa Pasar Modal: Suatu Tinjauan Atas Perkara Perdata Terkait Transaksi Repo. Jurnal Bina Mulia Hukum, Vol 4 No. 1, P-ISSN: 2528-7273 E-ISSN: 25409034

Ema Rahmawati dan Rai Mantili, (2016). Penyelesaian Sengketa Melalui Lembaga Alternatif Jasa Keuangan di Sektor Jasa Keuangan. Padjadjaran Jurnal Ilmu Hukum. Vol 3 No. 2. ISSN 2460-1543 eISSN 2442-9325

Evelyn Larissa Florentia Wijaya, (2020). Perlindungan Hukum Konsumen Atas Kesamaan Bunyi Merek Terhadap Barang Yang Tidak Sejenis. Jurnal Cendekia Hukum. Vol 5 No. 2.

Haidar dan Fadilah, (2015). Perlindungan Hukum Bagi Investor Terhadap Praktik Kejahatan Insider Trading 
Pada Pasar Modal di Indonesia. Jurnal Cita Hukum. Vol 3 No. 1.

Iskandar dan Dadang, (2017) Penegakan Hukum Atas Kejahatan Perdagangan Orang Dalam (insider trading. Jurnal Yustisi. Vol 4 No. 1.

Jusuf Anwar, (2008). Penegakan Hukum dan Pengawasan Pasar Modal. Bandung: PT. Alumni.

Objectives and Principles of Securities Regulation, Internasional

Organization of Securities Commission (IOSCO), May 2017.

Rancangan Peraturan Otoritas Jasa Keuangan tentang Disgorgement dan Disgorgement Fund

Saskia dan Rani, (2015). Kajian Hukum Terhadap Perspektif Peranan Pengawasan Hukum Pasar Modal di
Indonesia. Jurnal Lex Et Societatis. Vol 3 No. 2.

Sudikno Mertokusumo, (2013). Hukum Acara Perdata Indonesia. Yogyakarta: Cahaya Atma Pustaka, Cet. Pertama.

Undang-Undang Nomor 8 Tahun 1995 tentang Pasar Modal

Undang-Undang Nomor 21 tahun 2011 tentang Otoritas Jasa Keuangan

Urska Velikonja, (2015). Public Compensation For Private Harm: Evidence From The SEC's Fair fund Distribution. Stanford Law Review Vo. 67, Iss 2. 